\title{
Onsite Sewage Treatment and Disposal Systems: Bacteria and Protozoa ${ }^{1}$
}

\author{
Mary Lusk, Gurpal S. Toor, and Tom Obreza²
}

This publication is part of a series titled Onsite Sewage Treatment and Disposal Systems, commonly referred to as septic systems. This series is intended to give state and local government officials, soil scientists, consulting engineers, Extension agents, and citizens a basic understanding of onsite wastewater treatment and the behavior of different wastewater-borne contaminants coming from septic systems.

\section{Introduction and Purpose}

The fate of three groups of microorganisms - bacteria, protozoa, and viruses - in wastewater is an important consideration in onsite sewage treatment and disposal systems (hereafter referred to as septic systems). Keeping pathogenic (disease-causing) microorganisms out of groundwater used for drinking water supplies is important to protect human health. The level of microorganisms in groundwater depends on the microorganism levels and the extent to which microorganisms are removed in the septic tank and drain field (also called the soil treatment unit, leach field, or soil absorption system). For an overview of septic systems, consult "Onsite Sewage Treatment and Disposal Systems: An Overview" by Toor et al. (2011) available at http://edis.ifas.ufl.edu/ss549.

Among microorganisms, bacteria are the most-studied group in septic systems because standard analytical methods for their detection have been developed. Bacteria are single-celled organisms with no membrane-enclosed nucleus or other organelles. They range in size from 0.2 to $2.0 \mu \mathrm{m}$ in diameter. Bacteria are essential for proper functioning of septic systems because they facilitate much of the conversion of organic matter into less complex compounds in the septic tank, and they provide most of the wastewater treatment associated with septic systems that occurs in the drain field.

While the vast majority of bacteria are not harmful, certain types of bacteria cause disease in humans and animals.

Examples of waterborne diseases caused by bacteria include cholera, dysentery, shigellosis, and typhoid fever. Cholera outbreaks, for example, have often been linked to drinking water contaminated with pathogenic bacteria from human sewage. Table 1 summarizes a few of the bacteria in wastewater and the human diseases and symptoms they cause.

Unlike bacteria, protozoa are single-celled organisms with membrane-enclosed organelles and are about 10 times larger than bacteria. The presence of protozoa in wastewater may be beneficial because they prey on pathogenic bacteria (Horan 2003). Some protozoa cause diseases in the human intestinal tract and produce cysts or oocysts that are excreted and become part of wastewater. These cysts can survive in the septic tank and the drain field for long periods. Protozoa - including Cryptosporidium parvum, Entameoba histolytica, and Giardia lamblia - are only present in wastewater that comes from a household with an infected individual. Other protozoa called microsporidia,

1. This document is SL350, one of a series of the Soil and Water Science Department, Florida Cooperative Extension Service, Institute of Food and Agricultural Sciences, University of Florida. Original publication date July 2011. Visit the EDIS website at http://edis.ifas.ufl.edu.

2. Mary Lusk, PhD student; Gurpal S. Toor, assistant professor, Soil and Water Science Department, Gulf Coast REC--Wimauma, FL 33598; and Tom Obreza, interim associate dean and professor, Soil and Water Science Department; Florida Cooperative Extension Service, Institute of Food and Agricultural Sciences, University of Florida, Gainesville, FL 32611. 
such as Encephalitozoon sp., are also a health concern in septic systems. Table 2 includes a few of the protozoa present in wastewater and the diseases and symptoms they can cause in humans.

The purpose of this article is to characterize the behavior of bacteria and protozoa in septic systems. This publication reports the sources of bacteria and protozoa in wastewater, discusses diseases associated with drinking water contaminated with wastewater, and then details their fate in septic systems. To learn about the behavior of viruses in septic systems, see an accompanying article in this series, "Onsite Sewage Treatment and Disposal Systems: Viruses" (Toor et al. 2011) available at http://edis.ifas.ufl.edu/ss553.

\section{Sources and Types of Bacteria and Protozoa in Domestic Wastewater}

The main source of bacteria and protozoa in wastewater is human feces. Other minor sources include sputum, vomitus, contaminated clothing that goes through a washing machine, and normal skin flora that enters bath or shower water (U.S. EPA 2011). The U.S. EPA (2011) reports that within just one gram of human feces there are one trillion bacteria of various types. There are too many types of bacteria present in wastewater to enumerate. Thus, in most cases, indicator bacteria such as fecal coliforms and fecal streptococci are measured in wastewater because the task of detecting all possible microorganisms is complex and cost-prohibitive. The use of indicator bacteria is based on the assumption that fecal bacteria in the wastewater are survivors of the intestinal flora and that the presence of fecal coliforms and fecal streptococci can be used to reflect the possible presence of all human pathogens in wastewater. Table 3 summarizes typical bacterial counts for raw wastewater and septic tank effluent.

Note that only a few organisms of E. coli O157:H7, Salmonellae, and Shigellae ( $<20$ organisms) can cause infections in humans, and they are present in much higher concentrations in wastewater (more than 10,000 organisms). The infectious doses of protozoa are even lower (1 organism) compared with their higher concentrations in wastewater (Table 4). The implication is that more than 99\% removal of bacteria and protozoa in septic systems and the surrounding environment is necessary to protect public health.

\section{Behavior of Bacteria and Protozoa in the Soil Treatment Unit of Septic Systems}

Characterizing the fate of microorganisms in the drain field is a necessary step to properly design and site a septic system. Properly engineered systems will do much to prevent groundwater contamination and associated disease outbreaks. Bacteria in wastewater are removed by physical straining (also called mechanical filtration) and

Table 1. Bacteria found in septic system wastewater, associated diseases caused, and symptoms.

\begin{tabular}{|l|l|l|}
\hline \multicolumn{1}{|c|}{ Bacteria } & \multicolumn{2}{|c|}{ Disease caused } \\
\hline Escherichia coli (pathogenic) & Gastroenteritis & Diarrhea \\
\hline Legionella pneumophila & Legionellosis (Legionnaires' disease) & Malaise, acute respiratory illness \\
\hline Leptospira spp. & Leptospirosis (Weil's disease) & Jaundice, fever \\
\hline Salmonella typhii & Typhoid fever & High fever, diarrhea \\
\hline Salmonella & Salmonellosis & Vomiting, abdominal pain, diarrhea \\
\hline Shigella & Shigellosis (Bacillary dysentery) & Dysentery \\
\hline Vibrio cholerae & Cholera & Diarrhea, dehydration \\
\hline Yersinia enterocolitica & Gastroenteritis & Diarrhea \\
\hline Source: FDOH (2011) and Lowe et al. (2007). & & \\
\hline
\end{tabular}

Table 2. Protozoa found in septic system wastewater, associated diseases caused, and symptoms.

\begin{tabular}{|l|l|l|}
\hline \multicolumn{1}{|c|}{ Protozoa } & \multicolumn{1}{|c|}{ Disease caused } \\
\hline Cryptosporidium parvum & Cryptosporidiosis & Diarrhea, low-grade fever \\
\hline Giardia lamblia & Giardiasis & Diarrhea, nausea, indigestion \\
\hline Entamoeba histolytica & Amoebic dysentery & Diarrhea, dysentery \\
\hline Balantidium coli & Balantidiasis & Diarrhea, dysentery, intestinal ulcers \\
\hline Cyclospora & Cyclosporasis & $\begin{array}{l}\text { Severe diarrhea, nausea, vomiting, severe stomach } \\
\text { cramps }\end{array}$ \\
\hline Source: Lowe et al. (2007). & & \\
\hline
\end{tabular}


by adsorption to soil surfaces. A comprehensive review of these two processes that remove bacteria from effluent is provided by Stevik et al. (2004) and is briefly summarized below:

Physical Straining. Bacteria and protozoa can be removed from the effluent by straining through the soil, which involves soil pores smaller than the bacteria; these pores block the physical movement of bacteria. Table 5 outlines the factors that affect physical straining of bacteria from effluent.

Adsorption. If soil pores are larger than the bacteria, then adsorption to soil surfaces becomes the dominant means of bacterial removal. Bacteria are electrically-charged colloidal particles that possess a net negative charge at their surface. Thus, factors that reduce the repulsive forces between the clay particles and bacteria will enhance adsorption. Factors that may influence the adsorption of bacterial cells to soils are categorized in three groups-physical, chemical, and microbiological (Table 6).

Aside from straining and adsorption, bacteria present in septic tank effluent may be attenuated in the soil simply because they do not survive very well outside the human body. Factors affecting survival of enteric bacteria in soils include soil moisture content, temperature, $\mathrm{pH}$, organic matter content, antagonism from soil microflora, and bacterial type (Gerba and Britton 1984). Gerba et al.
(1975) reported that survival in favorable conditions (high moisture content, low temperature, alkaline $\mathrm{pH}$, and high organic matter content) may extend beyond 100 days. However, in non-favorable conditions (e.g., acid pH or dry sandy soils), bacterial cells may only survive 1 or 2 days (Sjogren 1994; Mawdsley et al. 1995). Comprehensive information on survival periods of several pathogens in soil-wastewater systems is presented by Stevik et al. (2004).

Little removal of protozoan cysts or oocysts may occur in septic tanks (Feachem et al. 1980). However, physical straining appears to be the main way cysts and oocysts of protozoa are removed in the drain field. As a result, soil texture, which determines pore size, has an important role in removing protozoa. For example, Damault et al. (2003) found that fine-textured soil removed 18 times more oocysts present in wastewater compared with coarsetextured soil. Macropores or preferential channels caused by earthworms or root channels in soil can also transport protozoa cysts, as Bradford et al. (2006) observed for Giardia lamblia.

\section{Environmental Impacts}

Water Quality Impacts: As discussed above, the degree to which straining of protozoa and both straining and adsorption of bacterial cells in a drain field keep them out of groundwater depends on a number of factors. Many of these factors derive from the nature of the drain field soil,

Table 3. Bacteria and pathogenic bacteria concentrations in raw wastewater and septic tank effluent.

\begin{tabular}{|c|c|c|}
\hline Bacteria & \multicolumn{2}{|c|}{ \# in wastewater ${ }^{1}$} \\
\hline Total bacteria & \multicolumn{2}{|c|}{$1 \times 10^{8} / 100 \mathrm{ml}$} \\
\hline Total coliform & \multicolumn{2}{|c|}{$2 \times 10^{6} / 100 \mathrm{ml}$} \\
\hline Fecal coliform & \multicolumn{2}{|c|}{$3 \times 10^{4} / 100 \mathrm{ml}$} \\
\hline Fecal streptococci & \multicolumn{2}{|c|}{$3 \times 10^{4} / 100 \mathrm{ml}$} \\
\hline Pathogenic bacteria & \# in effluent ${ }^{2}$ & Infectious dose (\# of organisms) ${ }^{2}$ \\
\hline Enteropathogenic Escherichia coli & $10^{5}-10^{8}$ & $\begin{array}{c}10 \text { for O157:H7 } \\
10^{6}-10^{7} \text { for other species }\end{array}$ \\
\hline Salmonellae & $0-10^{7}$ & $15-20$ \\
\hline Shigellae & $0-10^{7}$ & 10 \\
\hline Vibrio cholerae & $0-10^{7}$ & $10^{6}$ \\
\hline
\end{tabular}

Table 4. Protozoa concentrations in septic tank effluent.

\begin{tabular}{|l|c|c|}
\hline \multicolumn{1}{|c|}{ Pathogen } & \# in effluent & Infectious dose (\# of organisms) \\
\hline Cryptosporidium parvum & $10^{1}-10^{3} / 100 \mathrm{ml}$ & 1 \\
\hline Giardia lamblia & $10^{3}-10^{4} / 100 \mathrm{ml}$ & 1 \\
\hline Entamoeba histolytica & $0-10^{5} / 100 \mathrm{ml}$ & 1 \\
\hline Source: McCray et al. (2009). & & \\
\hline
\end{tabular}


Table 5. Factors influencing the physical straining (mechanical filtration) of bacteria in septic system effluent.

\begin{tabular}{|l|l|}
\hline \multicolumn{1}{|c|}{ Influencing Factor } & \multicolumn{1}{c}{ Comments } \\
\hline Nature of the soil & $\begin{array}{l}\text { - Clay, silt, and fine sand have pore sizes within the range of most bacterial cells; these soils } \\
\text { filter out bacteria. } \\
\text { - Presence of macropores increases preferential flow and decreases bacterial filtering. }\end{array}$ \\
\hline Bacterial cell size and shape & $\begin{array}{l}\text { - Larger cells are filtered out more effectively. } \\
\text { - Studies show that long, rod-shaped cells are filtered out less effectively (Weiss et al. 1995). }\end{array}$ \\
\hline Degree of water saturation & \begin{tabular}{l} 
- Higher flow rates result in decreased filtering of bacterial cells. \\
\hline Clogging
\end{tabular} \\
\hline & - With time, solid materials may accumulate at the infiltration surface, leading to clogging; this \\
& clogging may facilitate bacterial removal. \\
\hline
\end{tabular}

Source: Stevik et al. (2004).

Table 6. Factors influencing the adsorption of bacteria in septic system effluent to soil surfaces.

\begin{tabular}{|c|c|c|}
\hline Category & Influencing Factor & Comments \\
\hline \multirow[t]{4}{*}{ Physical } & Nature of the soil & $\begin{array}{l}\text { - Fine-textured soils have more adsorption sites because of a larger } \\
\text { surface area. } \\
\text { - Iron oxide coatings on soil particles encourage more adsorption. }\end{array}$ \\
\hline & Organic matter & $\begin{array}{l}\text { - Solid organic matter can increase surface area and bacterial } \\
\text { adsorption. } \\
\text { - Organic matter in the liquid may compete with bacterial cells for } \\
\text { adsorption sites. }\end{array}$ \\
\hline & Temperature & $\begin{array}{l}\text { - Higher temperatures encourage greater bacterial adsorption } \\
\text { (attributed to physiological changes in the organisms). }\end{array}$ \\
\hline & Water flow velocity & - Higher flow rate reduces adsorption capacity. \\
\hline \multirow[t]{2}{*}{ Chemical } & lonic strength & - Adsorption generally increases with increased ionic strength. \\
\hline & $\mathrm{pH}$ & - pH effects vary depending on the type of bacteria. \\
\hline \multirow[t]{3}{*}{ Microbiological } & Hydrophobicity & $\begin{array}{l}\text { - Hydrophobic bacteria generally adsorb to soil more readily than } \\
\text { hydrophilic bacteria. }\end{array}$ \\
\hline & Chemotaxis & $\begin{array}{l}\text { - Chemotaxis is defined as a directional movement toward (positive } \\
\text { chemotaxis) or away from (negative chemotaxis) higher chemical } \\
\text { concentrations. } \\
\text { - Bacteria are chemotactically attracted to many chemicals. }\end{array}$ \\
\hline & Bacterial concentration & $\begin{array}{l}\text { - Rate of adsorption generally increases with bacterial cell } \\
\text { concentration. }\end{array}$ \\
\hline
\end{tabular}

but may also include characteristics like septic tank density (number of septic systems per unit area of land) or loading rate (amount of wastewater per unit area of soil per unit of time). Surveys and monitoring studies have shown that the risk of surface and groundwater contamination from septic systems increases with conditions of high effluent loading rates, shallow water tables, high housing densities (septic systems), close proximity to surface waters, or fractured bedrock.

Even with the various factors that can affect bacterial removal, many researchers report high rates (95\%-99\%) of bacterial removal under septic systems (U.S. EPA 2011; Stevik et al. 2004; Hagedorn et al. 1981). However, most researchers point out that microbial reductions are sitedependent. For example, rapidly urbanizing coastal areas may be more prone to groundwater contamination from septic system derived bacteria, not only because of porous soil conditions, but also because of high septic tank density (Meeroff et al. 2008).

Several Florida studies have correlated bacterial removal with environmental conditions (Arnade 1999; Dillon et al. 1999; Bloetscher and VanCott 1999). All of these studies found that bacterial contributions to groundwater become more acute when coastal areas had high housing density and when saturated soil conditions occurred. In these cases, high loading rates during periods of saturated wet soils increased the transport of bacteria to groundwater. Such conditions afforded little opportunity for soil treatment in the drain field. However, it should be noted that septic tank effluent discharging to saturated soil is not allowed under Florida's current septic system regulations. While older systems that do not meet the groundwater separation 
requirements may directly contaminate groundwater, systems installed since 1984 have been required to meet a 2-foot separation from the wet season water table. Most septic systems included in the previously mentioned studies would not meet current regulations.

In light of environmental and social factors that may contribute to increased bacterial loading to groundwater in Florida, several new onsite technologies offer advanced treatment of the effluent in an effort to reduce bacterial counts before effluent reaches the soil. For example, aerobic treatment units (ATU) can be fitted with disinfection devices to remove bacteria before effluent is discharged to the drain field. However, several researchers have found that ATUs must be maintained properly or they quickly lose their disinfection capability (Levett et al. 2010). Moelants et al. (2008) and Roeder and Brookman (2006) both report ATU effluent with higher than expected bacterial counts. Levett et al. (2010) reported fecal coliform in $71 \%$ of ATU effluents. These authors linked elevated bacteria concentrations to poor maintenance of the unit and asserted that quarterly maintenance of the units by a service agent could significantly decrease the level of indicator bacteria in effluent.

Disease Outbreaks Incidences: How well an onsite system removes bacteria has important implications for protecting human health. Septic systems rank highest among wastewater treatment techniques in the total volume of wastewater discharged to groundwater, contributing 800 billion gallons to the subsurface every year (Yates 2006). If septic systems have inadequate design, construction, siting, operation, or maintenance, they can be sources of groundwater contamination. Yates (2006) and DeBorde et al. (1998) report that the majority of waterborne disease outbreaks are caused by bacteria and viruses present in domestic sewage and that septic systems are the most frequently reported cause of groundwater contamination associated with disease outbreaks.

One of the largest outbreaks of waterborne disease in the United States involving contaminated groundwater occurred in Florida in 1974, when approximately 1,200 cases of acute gastrointestinal illness occurred in Richmond Heights, Dade County. An epidemiologic investigation and a dye tracer study disclosed that a public water well was contaminated by a septic system approximately 125 feet (38 meters) from the well (Weissman et al. 1976). Since this outbreak occurred in 1974, it is likely that the septic system in question did not meet current standards requiring a 2-foot separation between the drain field and the wet season water table.
Yates (2006) and Ozkan et al. (2007) both reported increased disease incidence as distance from septic systems to groundwater wells decreased. Other researchers have noted an increase in disease outbreaks in areas with high septic tank density, which the U.S. EPA defines as greater than 40 septic tanks per square mile (Katz et al. 2010; Borchardt et al. 2003). Fong et al. (2007) investigated a large outbreak of waterborne illness in Ohio during the summer of 2004. They correlated the outbreak with extreme rainfall events occurring just before the summer that caused high water tables and increased interaction of septic tank effluent with groundwater.

Compared with the many studies conducted to determine environmental impacts of bacteria, relatively few studies have been conducted on other microorganisms such as protozoa because there is a lack of analytical methods to detect the concentrations and a risk of introducing pathogens in the environment using dosing studies. For more information on protozoa, see Deng and Cliver (1995) and Snowden et al. (1989) for information on degradation of Giardia in mixed waste and Logan et al. (2001) for information on transport of Cryptosporidium parvum in sand filters.

\section{Summary}

Bacteria and protozoa from domestic wastewater can cause numerous human illnesses, so monitoring the behavior of bacteria in septic systems is a public health priority. Soils have the ability to filter bacterial cells and prevent the transport of bacteria to groundwater. Soils provide this service by physically straining protozoa and by both physically straining and adsorbing bacteria to soil surfaces. While many researchers report very high bacterial removal by soils, the rate of removal depends on local conditions. In Florida, problems associated with porous sandy soils, high water tables, and increasing human populations can be avoided if septic systems are properly constructed and sited according to state regulations. The most commonly recommended means of reducing bacterial transport from septic systems is to increase distances from the drain field to groundwater, thus increasing the chances for removal of pathogens and reducing chances for pathogens transport to groundwater.

Consult the following EDIS articles in this series for more information on these topics:

SS549/SL347 - Onsite Sewage Treatment and Disposal Systems: An Overview 
SS550/SL348 - Onsite Sewage Treatment and Disposal Systems: Nitrogen

SS551/SL349 - Onsite Sewage Treatment and Disposal Systems: Phosphorus

SS553/SL351 - Onsite Sewage Treatment and Disposal Systems: Viruses

SS554/SL352 - Onsite Sewage Treatment and Disposal Systems: Toxic Organic Chemicals

\section{References}

Arnade, L. "Seasonal Correlation of Well Contamination and Septic Tank Distance." Ground Water 37, no. 6 (1999):920-3.

Bloetscher, F., and W.R. VanCott. "Impact of Septic Tanks on Wellhead Protection Efforts." Florida Water Resources Journal 51, no. 2 (1999):38-41.

Borchardt, M.A., P. Chyou, E.O. DeVries, and E.A. Belongia. "Septic System Density and Infectious Diarrhea in a Defined Population of Children." Environmental Health Perspectives 11, no. 5 (2003):742-8.

Bradford, S.A., Y.F. Tadassa, and Y. Pachepsky. “Transport of Giardia and Manure Suspensions in Saturated Porous Media." Journal of Environmental Quality 35, no. 3 (2006):749-57.

Darnault, C.J., P. Garnier, Y.J. Kim, K.L. Oveson, T.S. Steenhuis, J.Y. Parlange, M. Jenkins, W.C. Ghiorse, and P. Baveye. "Preferential Transport of Cryptosporidium parvum Oocysts in Variably Saturated Subsurface Environments." Water Environ Res 75, no. 2 (2003):113-20.

DeBorde, D.C., W.W. Woessner, B. Lauerman, and P.N. Ball. "Virus Occurrence and Transport in a School Septic System and Unconfined Aquifer." Ground Water 36, no. 5 (1998):825-34.

Deng, M.Y., and D.O. Cliver. "Mixed Waste Studies with Viruses and Giardia." Proceedings of the Seventh National Symposium on Individual and Small Community Sewage Systems, ASAE, St. Joseph, MI, 1995.

Dillon, K.S., D.R. Corbett, J.P. Chanton, W.C. Burnett, and D.J. Furbish. "The Use of Sulfur Hexafluoride as a Tracer of Septic Tank Effluent in the Florida Keys." Journal of Hydrology 220 (1999):129-40.
Feachem, R.G., D.J. Bradley, H. Garelick, and D.D. Mara. Health Aspects of Excreta and Sullage Management - A State-of-the-Art Review. Washington, D.C.: The World Bank, 1980.

Fong, T., L.S. Mansfield, D.L. Wilson, D.J. Schwab, S.L. Molloy, and J.B. Rose. "Massive Microbiological Groundwater Contamination Associated with a Waterborne Outbreak in Lake Erie, South Bass Island, Ohio." Environmental Health Perspectives 115, no. 6 (2007):856-64.

Gerba, C.P., and G. Britton. "Microbial Pollutants: Their Survival and Transport Patterns to Groundwater." In Groundwater Pollution Microbiology, G. Britton and C. Gerba (eds.). New York: John Wiley and Sons, 1984.

Gerba, C.P., C. Wallis, and J.L. Melnick. "Fate of Wastewater Bacteria and Viruses in Soil." Journal of Irrigation and Drainage 101 (1975):157-75.

Hagedorn, C., E.L. McCoy, and T.M. Rahe. "The Potential for Ground Water Contamination from Septic Effluents." Journal of Environmental Quality 10 (1981):1-8.

Horan, N.J. "Faecal Indicator Organisms." In The Handbook of Water and Wastewater Microbiology D. Mara and N.J. Horan (eds.), 104-12. San Diego, CA: Academic Press, 2003.

Katz, B.G., S.M. Eberts, and L.J. Kauffman. "Using Cl/Br ratios and Other Indicators to Assess Potential Impacts on Groundwater Quality from Septic Systems: A Review and Examples from Principle Aquifers in the United States." Journal of Hydrology 397 (2010):151-66.

Levett, K.J., J.L. Vanderzalm, D.W. Page, and P.J. Dillon. "Factors Affecting the Performance and Risks to Human Health of On-site Wastewater Treatment Systems." Water Science and Technology 62 (2010):1499-509.

Logan, A.J., T.K. Stevik, R.L. Siegrist, and R.M. Ronn. "Transport and Fate of Cryptosporidium parvum in Intermittent Sand Filters during Wastewater Treatment." Proceedings of the Ninth National Symposium on Individual and Small Community Sewage Systems, ASAE, St. Joseph, MI, 2001.

Lowe, K.S., N.K. Rothe, J.M.B. Tomaras, K. DeJong, M.B. Tucholke, J.E. Drewes, J.E. McCray, and J. Munakata-Marr. "Influent Constituent Characteristics of the Modern Waste Stream from Single Sources: Literature Review." Water 
Environment Research Foundation. Technical Report 04-DEC-1a, 2007.

Mawdsley, J.L., R.D. Bardgett, R.J. Merry, B.F. Pain, and M.K. Theodorou. "Pathogens in Livestock Waste, Their Potential for Movement through Soil and Environmental Pollution." Applied Soil Ecology 2 (1995):1-15.

McCray, J., K.S. Lowe, M. Geza, J. Drewes, S. Roberts, A. Wunsch, D. Radcliffe, J. Amador, J. Atoyan, T. Boving, D. Kalen, and G. Loomis. "State of the Science: Review of Quantitative Tools to Determine Wastewater Soil Treatment Unit Performance." Water Environment Research Foundation. Technical Report DEC1R06, 2009.

Meeroff, D.E., F. Bloetscher, T. Bocca, and F. Morin. "Evaluation of Water Quality Impacts of Onsite Treatment and Disposal Systems on Urban Coastal Waters." Water Air Soil Pollution 192 (2008):11-24.

Moelants, N., G. Jannsen, I. Smets, and J. VanImpe. "Field Performance Assessment of Onsite Individual Wastewater Treatment Systems." Water Science and Technology 58 (2008):1-6.

Ozkan, S., H. Tuzun, N. Gorer, M. Ceyhan, S. Aycan, S. Albayrak, and M.A. Bumin. "Water Usage Habits and the Incidence of Diarrhea in Rural Ankara, Turkey." Transactions of the Royal Society of Tropical Medicine and Hygiene 101, no.1 (2007):1131-5.

Roeder, E., and W. Brookman. "Performance of Aerobic Treatment Units: Monitoring Results from the Florida Keys." Journal of Environmental Health 69, no.4 (2006):17-22.

Sjogren, R.E. "Prolonged Survival of an Environmental Escherichia coil in Laboratory Soil Microcosms." Water Air Soil Pollution 75 (1994):389-403.

Snowden, J.A., D.O. Clover, and J.C. Converse. "Human and Animal Wastes Mixed for Disposal to Land: Inactivation of Viruses and Parasites in a Laboratory Model." Proceedings of the Fifth National Symposium on Individual and Small Community Sewage Systems, ASAE, St. Joseph, MI, 1989.

Stevik, T.K., K. Aa, G. Ausland, and J.F. Hanssen. "Retention and Removal of Pathogenic Bacteria in Wastewater Percolating through Porous Media: A Review." Water Research 38 (2004):1355-67.
Toor, G.S., M. Lusk, and T. Obreza. “Onsite Sewage Treatment and Disposal Systems: An Overview." University of Florida - IFAS, Gainesville, FL. Accessed July 8, 2011. http://edis.ifas.ufl.edu/ss549.

U.S. EPA. 2011. A Homeowner's Guide to Septic Systems. Accessed July 8, 2011. http://www.epa.gov/owm/septic/ pubs/homeowner_guide_long.pdf.

Weiss, T.H., A.L. Mills, G.M. Hornberger, and J.S. Herman. "Effect of Bacterial Shape on Transport of Bacteria in Porous Media." Environmental Science and Technology 29 (1995):1737-40.

Weissman, J.B., G.F. Craun, D.N. Lawrence, R.A. Pollard, M.S. Saslaw, and E.J. Gangarosa. "An Epidemic of Gastroenteritis Traced to a Contaminated Public Water Supply." American Journal of Epidemiology 103 (1976):391.

Yates, M.V. "Septic Tank Density and Groundwater Contamination." Ground Water 23, no. 5 (2006):586-91. 